\title{
Lactobacillus fabifermentans sp. nov. and Lactobacillus cacaonum sp. nov., isolated from Ghanaian cocoa fermentations
}

Correspondence

Katrien De Bruyne

Katrien.DeBruyne@UGent.be

\author{
Katrien De Bruyne, ${ }^{1}$ Nicholas Camu, ${ }^{2}$ Luc De Vuyst ${ }^{2}$ \\ and Peter Vandamme ${ }^{1}$
}

\author{
${ }^{1}$ Laboratory of Microbiology, Ghent University, Ledeganckstraat 35, B-9000 Ghent, Belgium \\ ${ }^{2}$ Research Group of Industrial Microbiology and Food Biotechnology (IMDO), Department of \\ Applied Biological Sciences and Engineering, Vrije Universiteit Brussel, Pleinlaan 2, B-1050 \\ Brussels, Belgium
}

\begin{abstract}
Two Gram-positive bacterial strains, LMG $24284^{\top}$ and LMG $24285^{\top}$, were isolated from different spontaneous cocoa bean heap fermentations in Ghana. Analysis of their 16S rRNA gene sequences indicated that they were members of the Lactobacillus plantarum and Lactobacillus salivarius species groups, respectively. DNA-DNA hybridization experiments with their nearest phylogenetic neighbours demonstrated that both strains represented novel species that could be differentiated from their nearest neighbours by pheS sequence analysis, whole-cell protein electrophoresis, fluorescent amplified fragment length polymorphism analysis and biochemical characterization. Therefore, two novel Lactobacillus species are proposed, Lactobacillus fabifermentans sp. nov. (type strain LMG $24284^{\top}=\mathrm{DSM} 21115^{\top}$ ) and Lactobacillus cacaonum sp. nov. (type strain LMG $24285^{\top}=$ DSM $21116^{\top}$ ).
\end{abstract}

In chocolate manufacture, the desired characteristic flavour is influenced by the cocoa cultivar, cocoa bean fermentation, drying and roasting of the beans and final processing (Camu et al., 2008; Hansen et al., 1998; Schwan \& Wheals, 2004; Thompson et al., 2001). Natural cocoa bean fermentation is being studied intensively (Camu et al., 2007, 2008; De Vuyst et al., 2008; Lagunes Gálvez et al., 2007; Nielsen et al., 2007). In this process, lactic acid bacteria are responsible for the conversion of citric acid and sugars into mainly lactic acid. Biodiversity studies report lactobacilli as the dominant species in the fermentation (Camu et al., 2007, 2008); species of the genera Leuconostoc, Pediococcus, Weissella and Lactococcus have also been reported (Camu et al., 2008; Carr et al., 1979; Passos et al., 1984a, b; Thompson et al., 2001). The population dynamics of lactic acid bacteria during spontaneous heap fermentations of cocoa beans in Ghana have been studied by Camu et al. (2007). In the course of this biodiversity study, two lactobacillus strains that could not be identified at the species level as belonging to any existing species were isolated. In the present study,

Abbreviation: FAFLP, fluorescent amplified fragment length polymorphism.

The GenBank/EMBL/DDBJ accession numbers for the 16S rRNA gene sequences of LMG $24284^{\top}$ and LMG $24285^{\top}$ are AM905388 and AM905389, respectively. additional analyses allocated these strains to two novel Lactobacillus species.

Strains LMG $24284^{\mathrm{T}}$ and LMG $24285^{\mathrm{T}}$ were isolated during the main crop of 2005 (October-December 2005) in New Tafo, Ghana, from fermenting cocoa beans, which were sampled both for microbiological analysis and for plating, isolation and monitoring of lactic acid bacteria as described by Camu et al. (2007). The isolates were checked for purity by microscopy and catalase and oxidase tests were performed. Dereplication and preliminary identification of all isolates was obtained by rep-PCR using the $(\mathrm{GTG})_{5}$ primer (Gevers et al., 2001). In the numerical analysis of $(\mathrm{GTG})_{5}$ profiles, strains LMG $24284^{\mathrm{T}}$ and LMG $24285^{\mathrm{T}}$ occupied distinct positions in the dendrogram.

The phylogenetic position of both strains was investigated by $16 \mathrm{~S}$ rRNA gene sequence analysis, performed as described by De Bruyne et al. (2008). FASTA analysis of both 16S rRNA gene sequences [continuous stretches of 1532 bp (strain LMG $24284^{\mathrm{T}}$ ) and 1527 bp (strain LMG $\left.24285^{\mathrm{T}}\right)$ ] identified members of the genus Lactobacillus as the most closely related bacteria. 16S rRNA gene sequence analysis of strain LMG $24284^{\mathrm{T}}$ indicated that it belonged to the Lactobacillus plantarum species group. 16S rRNA gene sequence similarities between strain LMG $24284^{\mathrm{T}}$ and the type strains of all species in this group were at least $98.2 \%$, i.e. similarities of $98.8,98.7,98.6$ and $98.2 \%$ to the type strains of Lactobacillus pentosus, L. paraplantarum, L. 
plantarum subsp. plantarum and L. plantarum subsp. argentoratensis, respectively. Strain LMG $24285^{\mathrm{T}}$ belonged to the Lactobacillus salivarius group with Lactobacillus mali LMG $6899^{\mathrm{T}}$ (97.5\% 16S rRNA gene sequence similarity) as the nearest neighbour; 16S rRNA gene sequence similarities with the type strains of all other species in this group were below $97 \%$. The obtained $16 \mathrm{~S}$ rRNA gene sequences of strains LMG $24284^{\mathrm{T}}$ and LMG $24285^{\mathrm{T}}$ and sequences of the type strains of species of both groups (retrieved from GenBank/EMBL) were aligned using CLUSTAL_X. A phylogenetic neighbour-joining tree was constructed using the BioNumerics software package, version 4.61 (Applied Maths). The statistical reliability of the topology of the neighbour-joining tree was evaluated by bootstrap analysis of 500 replicates (Fig. 1). Maximum-parsimony and maximum-likelihood cluster analysis confirmed the tree topology obtained by the neighbour-joining method (data not shown). However, analysis of $16 \mathrm{~S}$ rRNA gene sequences often does not enable closely related Lactobacillus species to be differentiated, e.g. members of the L. plantarum species group (Fig. 1), where a maximum interspecies variation of $1.3 \%$ is observed. The usefulness and accuracy of any bacterial species identification system depends on the distinction between intraspecific variation and interspecific divergence in selected loci (Meyer \& Paulay, 2005). In the search for an accurate identification system, a higher degree of resolution was obtained when using phenylalanyl-tRNA synthase alpha subunit (pheS)

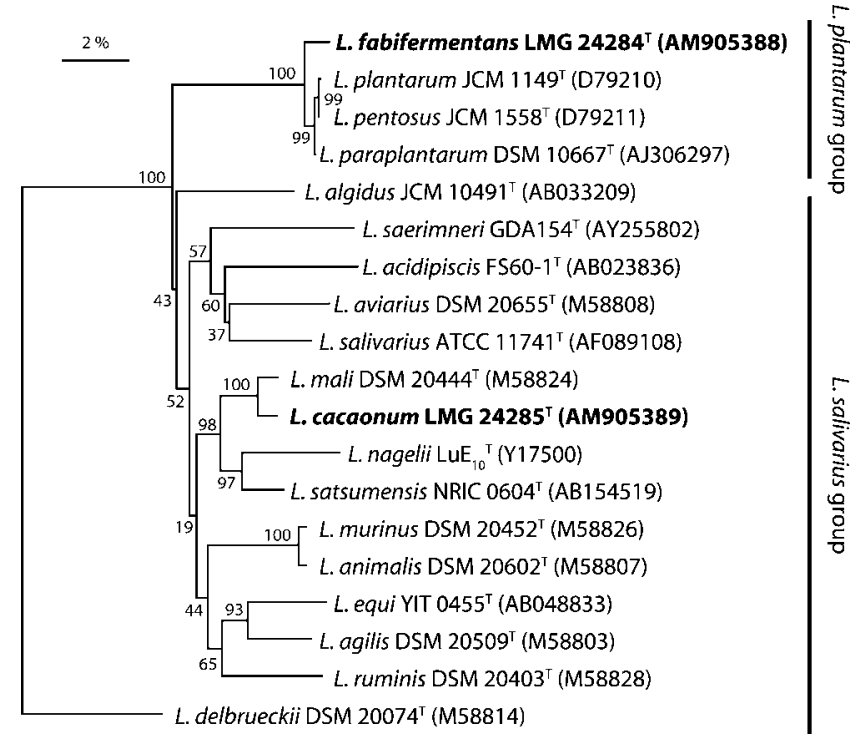

Fig. 1. Phylogenetic neighbour-joining tree based on $16 \mathrm{~S}$ rRNA gene sequences showing the relationship between $L$. fabifermentans LMG $24284^{\top}$, L. cacaonum LMG $24285^{\top}$ and other strains belonging to the $L$. plantarum and $L$. salivarius species groups, respectively. Lactobacillus delbrueckii subsp. delbrueckii DSM $20074^{\top}$ was used as the outgroup organism. Bootstrap values (\%) based on 500 tree replications are indicated at branching points. Bar, $2 \%$ sequence divergence. partial gene sequences to differentiate members of the genus Lactobacillus (Naser et al., 2007). The conditions for amplification and sequencing of the phes genes from strains LMG $24284^{\mathrm{T}}$ and LMG $24285^{\mathrm{T}}$ were as described by Naser et al. (2007). The primer combination pheS-21-F/ pheS-23-R was applied to amplify the target genes of both strains. Additional sequence data from type strains within the two species groups under discussion were retrieved from the study of Naser et al. (2007). The pheS phylogenetic trees are based on the neighbour-joining method and were obtained by importing the external sequence alignments from CLUSTAL_X into the BioNumerics software package. Within the L. plantarum species group, strain LMG $24284^{\mathrm{T}}$ showed a maximum pheS gene sequence similarity value of $81.9 \%$ to $L$. pentosus LMG $10755^{\mathrm{T}}$. For strain LMG $24285^{\mathrm{T}}$, the highest pheS gene sequence similarity value was $85.0 \%$ with L. nagelii $\mathrm{LMG}$ $21593^{\mathrm{T}}$. Fig. 2 clearly shows a higher resolution than the $16 \mathrm{~S}$ rRNA gene sequence analysis and suggests that strains LMG $24284^{\mathrm{T}}$ (Fig. 2a) and LMG $24285^{\mathrm{T}}$ (Fig. 2b) both represent novel Lactobacillus species.

The relatedness of the two cocoa isolates with their nearest neighbours was further investigated by SDS-PAGE of whole-cell proteins and fluorescent amplified fragment length polymorphism (FAFLP) analysis. SDS-PAGE of cellular proteins was performed as described by Pot et al.

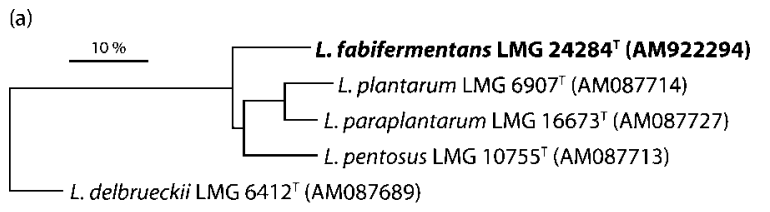

(b)

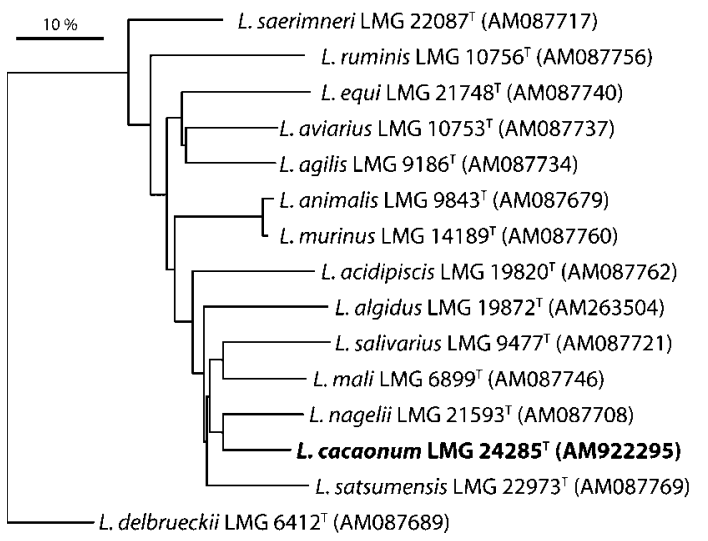

Fig. 2. Neighbour-joining analysis of the pheS gene sequences of Lactobacillus type strains belonging to the L. plantarum species group (a) and the L. salivarius species group (b). Distance estimations were obtained by the Kimura-2 model. L. delbrueckii subsp. delbrueckii LMG $6412^{\top}$ was included as the outgroup organism. Bars, $10 \%$ sequence divergence. 


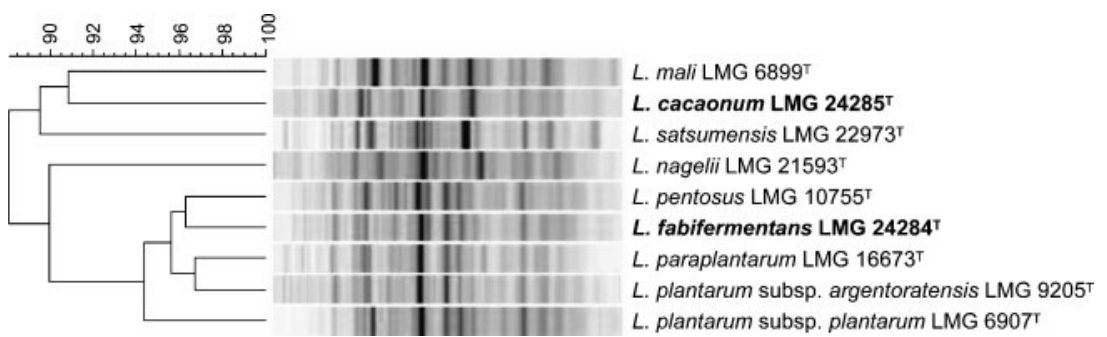

Fig. 3. Cluster analysis of whole-cell protein profiles and dendrogram derived from UPGMA linkage of correlation coefficients of $L$. fabifermentans sp. nov. LMG $24284^{\top}$ and the type strains of all species in the $L$. plantarum species group and those of $L$. cacaonum sp. nov. LMG $24285^{\top}$ and its closest phylogenetic neighbours.
(1994). Densitometric analysis, normalization and interpolation of protein profiles of strains LMG $24284^{\mathrm{T}}$ and LMG $24285^{\mathrm{T}}$ were performed and the resulting profiles were added to the in-house database. Numerical analysis was performed using the BIONUMERICS software package, version 4.61 (Applied Maths). The whole-cell protein profiles of strains LMG $24284^{\mathrm{T}}$ and LMG $24285^{\mathrm{T}}$ were clearly different from those of the type strains of their nearest phylogenetic neighbours (Fig. 3). Similarly, FAFLP analysis performed as described by Franz et al. (2006) confirmed the separate taxonomic status of both strains (Fig. 4).

Finally, genomic DNA was prepared as described by Stackebrandt \& Kandler (1979). DNA-DNA hybridizations were performed according to a modification (Goris et al., 1998) of the microplate method described by Ezaki et al. (1989). Reciprocal hybridization experiments were performed for each pair of strains. DNA-DNA hybridization values between strain LMG $24285^{\mathrm{T}}$ and L. mali LMG $6899^{\mathrm{T}}$ were $20 \pm 2 \%$, confirming that strain LMG $24285^{\mathrm{T}}$ represents a novel species. For strain LMG $24284^{\mathrm{T}}$, hybridizations were performed against representatives of all members of the L. plantarum group. Hybridization values between strain LMG $24284^{\mathrm{T}}$ and L. pentosus LMG $10755^{\mathrm{T}}$, L. paraplantarum LMG $16673^{\mathrm{T}}$, L. plantarum subsp. plantarum LMG $6907^{\mathrm{T}}$ and L. plantarum subsp. argentoratensis LMG $9205^{\mathrm{T}}$ were $16,16,26$ and $26 \%$, respectively, again confirming that strain LMG $24284^{\mathrm{T}}$ represents a novel species within the genus Lactobacillus.

The DNA G + C content was determined according to the enzymic DNA degradation method of Mesbah et al. (1989). The DNA nucleotide mixture was analysed chromatographically using a Waters Breeze HPLC system. A thermostable XBridge Shield RP18 column was used at $37{ }^{\circ} \mathrm{C}$ with $0.02 \mathrm{M} \quad \mathrm{NH}_{4} \mathrm{H}_{2} \mathrm{PO}_{4} \quad(\mathrm{pH} 4.0) / 1.5 \% \quad$ (v/v) acetonitrile as solvent. Non-methylated lambda phage

(a)

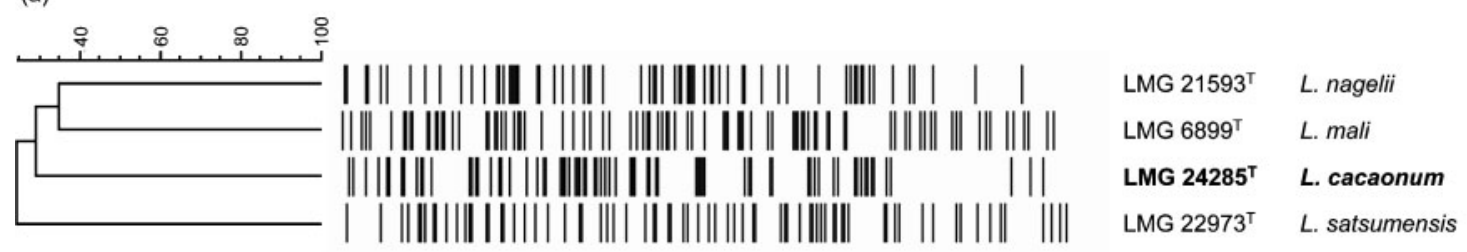

(b)

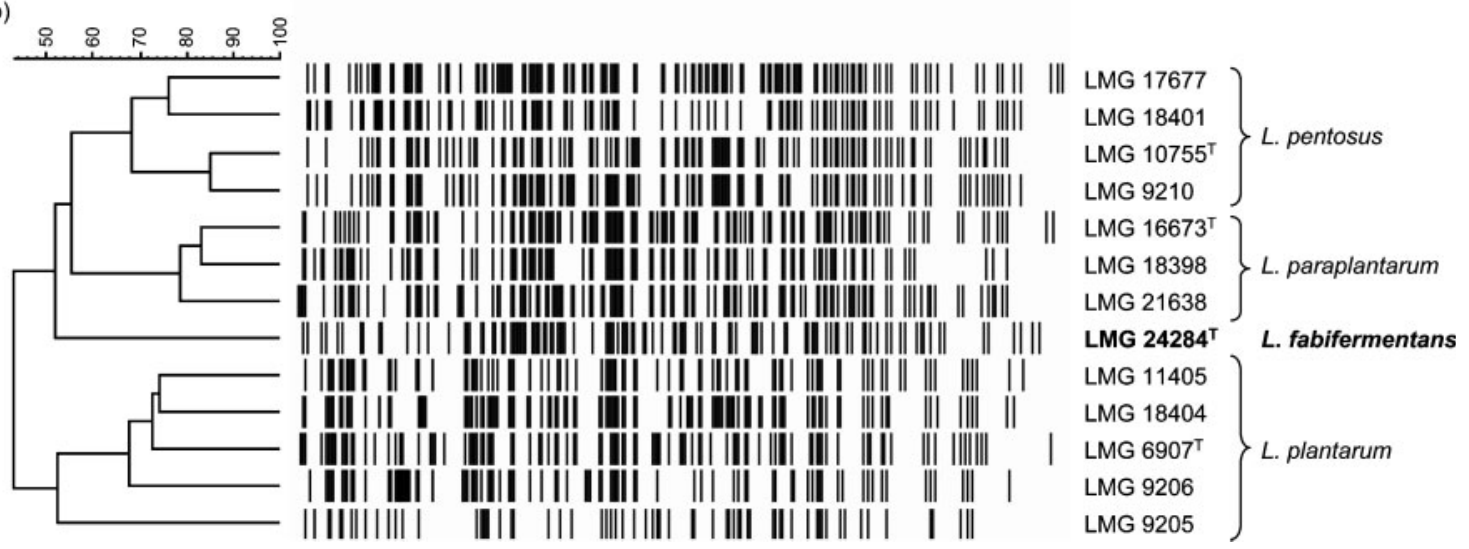

Fig. 4. FAFLP patterns and dendrograms based on the UPGMA linkage of Dice coefficients of $L$. cacaonum sp. nov. $L M G$ $24285^{\top}$ and its closest neighbours from the $L$. salivarius species group (a) and of $L$. fabifermentans sp. nov. LMG $24284^{\top}$ and representatives of the $L$. plantarum species group (b). 
DNA (Sigma) was used as calibration reference and Escherichia coli LMG 2093 DNA was used as control. The $\mathrm{G}+\mathrm{C}$ content of strain LMG $24285^{\mathrm{T}}$ was $34.5 \mathrm{~mol} \%$, which was comparable to that of $L$. mali (32-34 mol\%; Kato et al., 2000). The G $+\mathrm{C}$ content of strain LMG $24284^{\mathrm{T}}$ was $44.9 \mathrm{~mol} \%$, which was consistent with the $\mathrm{G}+\mathrm{C}$ contents determined for members of the $L$. plantarum group (44-47 mol\%; Bringel et al., 2005; Curk et al., 1996; Zanoni et al., 1987).

Cell and colony morphology were investigated after growth on MRS agar ( $\mathrm{pH} 5.4$; Oxoid) for $48 \mathrm{~h}$ aerobic incubation at $37^{\circ} \mathrm{C}$, except where stated otherwise. Conventional biochemical tests and growth characteristics were determined as described by De Bruyne et al. (2008). Carbohydrate fermentation tests were performed in duplicate using the API 50 CHL system (bioMérieux) and enzyme activities were tested in duplicate using the API ZYM system (bioMérieux), both following the manufacturer's instructions. For the detection of glucose metabolites and the proportion of Dand L-lactate, strains were grown for $24 \mathrm{~h}$ at $30{ }^{\circ} \mathrm{C}$ in MRS broth (pH 5.4; Oxoid). Detailed phenotypic descriptions are given in the species descriptions. Characteristics that differentiate LMG $24284^{\mathrm{T}}$ and LMG $24285^{\mathrm{T}}$ from their closest relatives are summarized in Table 1.

Based on the discussed polyphasic analysis, it is proposed that these strains should be classified as representatives of two novel Lactobacillus species: Lactobacillus fabifermentans sp. nov. (LMG $24284^{\mathrm{T}}$ ) and Lactobacillus cacaonum sp. nov. $\left(\right.$ LMG $\left.24285^{\mathrm{T}}\right)$.

\section{Description of Lactobacillus fabifermentans sp. nov.}

Lactobacillus fabifermentans (fa.bi.fer.men'tans. L. n. faba a bean; L. part. adj. fermentans fermenting; N.L. part. adj. fabifermentans of fermenting beans).

Cells are Gram-positive, catalase-negative, facultatively anaerobic and non-motile. Cells are long rods (1.0$3.0 \mu \mathrm{m}$ wide and $10.0 \mu \mathrm{m}$ long) that appear singly, in pairs or in short chains. Colonies are greyish white, opaque, smooth and circular with a convex elevation and an entire margin (diameter approx. $1.0 \mathrm{~mm}$ ). Growth is observed at temperatures from $10{ }^{\circ} \mathrm{C}$ (from day 8 of incubation) up to $37^{\circ} \mathrm{C}$ (immediate growth from day 1 of incubation). At $37{ }^{\circ} \mathrm{C}$, growth is observed in MRS broth ( $\mathrm{pH}$ 3.9). Growth occurs in MRS broth supplemented with $6 \% \mathrm{NaCl}$. The type strain (LMG $24284^{\mathrm{T}}$ ) produces lactic acid only as a metabolite from glucose. The ratio of production of D- and L-lactic acid isomers is $80: 20$. No gas production is observed. Arginine is deaminated. Acid is produced from L-arabinose, ribose, D-xylose, galactose, glucose, fructose, mannose, mannitol, $\mathrm{N}$-acetylglucosamine, amygdalin, arbutin, aesculin, salicin, cellobiose, maltose,

Table 1. Differential phenotypic features of strains LMG $24284^{\top}$ and LMG $24285^{\top}$ and closely related species

Strains: 1, L. cacaonum sp. nov. LMG $24285^{\mathrm{T}} ; 2$, L. mali $(n=15) ; 3$, L. fabifermentans sp. nov. LMG $24284^{\mathrm{T}} ; 4$, L. pentosus $(n=3) ; 5$, L. paraplantarum $(n=4) ; 6$, L. plantarum subsp. plantarum $(n=15) ; 7$, L. plantarum subsp. argentoratensis $(n=14)$. Data were adapted partially from Bringel et al. (2005), Carr \& Davies (1970), Curk et al. (1996) and Zanoni et al. (1987). +, $90 \%$ or more strains positive; -, $90 \%$ or more strains negative; d, 11-89\% of strains positive; NA, no data available. All taxa were negative for acid production from D-arabinose and L-xylose and positive for acid production from salicin (i.e. $90 \%$ or more strains negative or positive for reference species).

\begin{tabular}{|c|c|c|c|c|c|c|c|}
\hline Characteristic & 1 & 2 & 3 & 4 & 5 & 6 & 7 \\
\hline \multicolumn{8}{|l|}{ Acid from: } \\
\hline Cellobiose & + & $\mathrm{d}$ & + & + & + & + & + \\
\hline Galactose & - & $\mathrm{d}$ & + & + & + & + & + \\
\hline Lactose & - & - & - & + & + & + & + \\
\hline Maltose & + & - & + & + & + & + & + \\
\hline Mannitol & - & $\mathrm{d}$ & + & + & + & + & + \\
\hline Melibiose & - & NA & - & + & + & + & + \\
\hline Methyl $\alpha$-D-mannopyranoside & - & $\mathrm{NA}$ & - & - & - & + & - \\
\hline Melezitose & - & - & - & $\mathrm{d}$ & + & + & - \\
\hline Raffinose & - & - & - & + & - & $\mathrm{NA}$ & $\mathrm{NA}$ \\
\hline Ribose & - & - & + & + & + & NA & $\mathrm{NA}$ \\
\hline Sucrose & - & + & + & + & + & + & + \\
\hline Trehalose & - & + & + & + & + & + & + \\
\hline D-Xylose & - & - & + & + & - & - & - \\
\hline Growth at $45{ }^{\circ} \mathrm{C}$ & - & NA & - & - & - & - & - \\
\hline Lactic acid configuration & DL & $\mathrm{L}$ & DL & DL & DL & $\mathrm{DL}$ & $\mathrm{DL}$ \\
\hline Maximum $\mathrm{NaCl}$ concentration for growth (\%) & $-{ }^{*}$ & NA & 6 & NA & 8 & NA & NA \\
\hline DNA G $+C$ content $(\mathrm{mol} \%)$ & 34.5 & $32-34$ & 44.9 & $46-47$ & $44-45$ & $44-46$ & $44-46$ \\
\hline
\end{tabular}

${ }^{\star}$ No growth with added $\mathrm{NaCl}$ in MRS broth. 
sucrose, trehalose and gentiobiose. Acid is not produced from glycerol, erythritol, D-arabinose, L-xylose, adonitol, methyl $\beta$-D-xylopyranoside, sorbose, rhamnose, dulcitol, inositol, sorbitol, methyl $\alpha$-D-mannopyranoside, methyl $\alpha$ D-glucopyranoside, lactose, melibiose, inulin, melezitose, raffinose, starch, glycogen, xylitol, turanose, D-lyxose, Dtagatose, D- or L-fucose, D- or L-arabitol, gluconate or 2- or 5-ketogluconate.

The type strain is LMG $24284^{\mathrm{T}}\left(=\mathrm{DSM} 21115^{\mathrm{T}}\right)$, isolated from a cocoa bean heap fermentation in Ghana. The DNA $\mathrm{G}+\mathrm{C}$ content of the type strain is $44.9 \mathrm{~mol} \%$.

\section{Description of Lactobacillus cacaonum sp. nov.}

Lactobacillus cacaonum (ca.ca'o.num. N.L. n. cacao -onis a cacao bean; N.L. gen. pl. n. cacaonum of cacao beans).

Cells are Gram-positive, catalase-negative and facultatively anaerobic. Motility is not observed. Cells are small rods (0.8-1.0 $\mu \mathrm{m}$ wide and $2.0-3.0 \mu \mathrm{m}$ long) that appear singly, in pairs or short chains. Colonies are beige, opaque, smooth and circular with a convex elevation and an entire margin (diameter approx. $0.5 \mathrm{~mm}$ ). Growth is observed at temperatures from $10{ }^{\circ} \mathrm{C}$ (from day 6 of incubation) up to $37^{\circ} \mathrm{C}$ (immediate growth from day 1 of incubation). At $37{ }^{\circ} \mathrm{C}$, growth is observed in MRS broth ( $\mathrm{pH}$ 3.9). No growth is observed in MRS broth supplemented with $\mathrm{NaCl}$. Besides the production of (mainly) lactic acid, acetic acid is also observed as an end product of glucose metabolism. The type strain (LMG $24285^{\mathrm{T}}$ ) produces both $\mathrm{D}$ - and $\mathrm{L}$ lactate in a 10:90 ratio. No gas production is observed. Arginine is deaminated. Acid is produced from glucose, fructose, mannose, $\mathrm{N}$-acetylglucosamine, aesculin, salicin, cellobiose and maltose. Acid is not produced from glycerol, erythritol, D- or L-arabinose, ribose, D- or L-xylose, adonitol, methyl $\beta$-D-xylopyranoside, galactose, sorbose, rhamnose, dulcitol, inositol, mannitol, sorbitol, methyl $\alpha$ D-mannopyranoside, methyl $\alpha$-D-glucopyranoside, amygdalin, arbutin, lactose, melibiose, sucrose, trehalose, inulin, melezitose, raffinose, starch, glycogen, xylitol, gentiobiose, turanose, D-lyxose, D-tagatose, D- or L-fucose, D- or Larabitol, gluconate or 2- or 5-ketogluconate.

The type strain is LMG $24285^{\mathrm{T}}$ (=DSM $21116^{\mathrm{T}}$ ), isolated from a cocoa bean heap fermentation in Ghana. The DNA $\mathrm{G}+\mathrm{C}$ content of the type strain is $34.5 \mathrm{~mol} \%$.

\section{Acknowledgements}

This work was supported by the Federal Research Policy [Action for the promotion of and Cooperation with the Belgian Coordinated Collections of Microorganisms (C3/00/17)], the Research Council of the Vrije Universiteit Brussel (GOA project), the Institute for the Promotion of Innovation through Science and Technology in Flanders (IWT Project 040043) and Barry Callebaut NV. The cooperation of the Ghanaian Cocoa Producers' Alliance (COCOBOD, Accra, Ghana) and the Cocoa Research Institute of Ghana is highly appreciated. Approval was obtained by COCOBOD to cooperate with local farmers.

\section{References}

Bringel, F., Castioni, A., Olukoya, D. K., Felis, G. E., Torriani, S. \& Dellaglio, F. (2005). Lactobacillus plantarum subsp. argentoratensis subsp. nov., isolated from vegetable matrices. Int J Syst Evol Microbiol 55, 1629-1634.

Camu, N., De Winter, T., Verbrugghe, K., Cleenwerck, I., Vandamme, P., Takrama, J. S., Vancanneyt, M. \& De Vuyst, L. (2007). Dynamics and biodiversity of populations of lactic acid bacteria and acetic acid bacteria involved in spontaneous heap fermentation of cocoa beans in Ghana. Appl Environ Microbiol 73, 1809-1824.

Camu, N., González, Á., De Winter, T., Van Schoor, A., De Bruyne, K., Vandamme, P., Takrama, J. S., Addo, S. K. \& De Vuyst, L. (2008). Influence of turning and environmental contamination on the dynamics of populations of lactic acid and acetic acid bacteria involved in spontaneous cocoa bean heap fermentation in Ghana. Appl Environ Microbiol 74, 86-98.

Carr, J. G. \& Davies, P. A. (1970). Homofermentative lactobacilli of ciders including Lactobacillus mali nov. spec. J Appl Bacteriol 33, 768-774.

Carr, J. G., Davies, P. A. \& Dougan, J. (1979). Cocoa fermentation in Ghana and Malaysia I. Chatham, UK: Natural Resources Institute.

Curk, M. C., Hubert, J. C. \& Bringel, F. (1996). Lactobacillus paraplantarum sp. nov., a new species related to Lactobacillus plantarum. Int J Syst Bacteriol 46, 595-598.

De Bruyne, K., Camu, N., Lefebvre, K., De Vuyst, L. \& Vandamme, P. (2008). Weissella ghanensis sp. nov., isolated from a Ghanaian cocoa fermentation. Int J Syst Evol Microbiol 58, 2721-2725.

De Vuyst, L., Camu, N., De Winter, T., Vandemeulebroecke, K., Van de Perre, V., Vancanneyt, M., De Vos, P. \& Cleenwerck, I. (2008). Validation of the (GTG) $)_{5}$-rep-PCR fingerprinting technique for rapid classification and identification of acetic acid bacteria, with a focus on isolates from Ghanaian fermented cocoa beans. Int J Food Microbiol 125, 79-90.

Ezaki, T., Hashimoto, Y. \& Yabuuchi, E. (1989). Fluorometric deoxyribonucleic acid-deoxyribonucleic acid hybridization in microdilution wells as an alternative to membrane filter hybridization in which radioisotopes are used to determine genetic relatedness among bacterial strains. Int J Syst Bacteriol 39, 224-229.

Franz, C. M. A. P., Vancanneyt, M., Vandemeulebroecke, K., De Wachter, M., Cleenwerck, I., Hoste, B., Schillinger, U., Holzapfel, W. H. \& Swings, J. (2006). Pediococcus stilesii sp. nov., isolated from maize grains. Int J Syst Evol Microbiol 56, 329-333.

Gevers, D., Huys, G. \& Swings, J. (2001). Applicability of rep-PCR fingerprinting for identification of Lactobacillus species. FEMS Microbiol Lett 205, 31-36.

Goris, J., Suzuki, K., De Vos, P., Nakase, T. \& Kersters, K. (1998). Evaluation of a microplate DNA-DNA hybridization method compared with the initial renaturation method. Can J Microbiol 44, 1148-1153.

Hansen, C. E., del Olmo, M. \& Burri, C. (1998). Enzyme activities in cocoa beans during fermentation. J Sci Food Agric 77, 273-281.

Kato, Y., Sakala, R. M., Hayashidani, H., Kiuchi, A., Kaneuchi, C. \& Ogawa, M. (2000). Lactobacillus algidus sp. nov., a psychrophilic lactic acid bacterium isolated from vacuum-packaged refrigerated beef. Int $J$ Syst Evol Microbiol 50, 1143-1149.

Lagunes Gálvez, S., Loiseau, G., Paredes, J. L., Barel, M. \& Guiraud, J.-P. (2007). Study on the microflora and biochemistry of cocoa fermentation in the Dominican Republic. Int J Food Microbiol 114, 124-130.

Mesbah, M., Premachandran, U. \& Whitman, W. B. (1989). Precise measurement of the $\mathrm{G}+\mathrm{C}$ content of deoxyribonucleic acid by highperformance liquid chromatography. Int J Syst Bacteriol 39, 159-167. 
Meyer, C. P. \& Paulay, G. (2005). DNA barcoding: error rates based on comprehensive sampling. PLoS Biol 3, e422.

Naser, S. M., Dawyndt, P., Hoste, B., Gevers, D., Vandemeulebroecke, K., Cleenwerck, I., Vancanneyt, M. \& Swings, J. (2007). Identification of lactobacilli by pheS and rpoA gene sequence analyses. Int J Syst Evol Microbiol 57, 2777-2789.

Nielsen, D. S., Teniola, O. D., Ban-Koffi, L., Owusu, M., Andersson, T. S. \& Holzapfel, W. H. (2007). The microbiology of Ghanaian cocoa fermentations analysed using culture-dependent and culture-independent methods. Int J Food Microbiol 114, 168-186.

Passos, F. M. L., Lopez, A. S. \& Silva, D. O. (1984a). Aeration and its influence on the microbial sequence in cacao fermentations in Bahia, with emphasis on lactic acid bacteria. J Food Sci 49, 14701474.

Passos, F. M. L., Silva, D. O., Lopez, A., Ferreira, C. L. L. F. \& Guimarães, W. V. (1984b). Characterization and distribution of lactic acid bacteria from traditional cocoa bean fermentations in Bahia. $J$ Food Sci 49, 205-208.
Pot, B., Vandamme, P. \& Kersters, K. (1994). Analysis of electrophoretic whole-organism protein fingerprints. In Chemical Methods in Prokaryotic Systematics, pp. 493-521. Edited by M. Goodfellow \& A. G. O’Donnell. Chichester: Wiley.

Schwan, R. F. \& Wheals, A. E. (2004). The microbiology of cocoa fermentation and its role in chocolate quality. Crit Rev Food Sci Nutr 44, 205-221.

Stackebrandt, E. \& Kandler, O. (1979). Taxonomy of the genus Cellulomonas, based on phenotypic characters and deoxyribonucleic acid-deoxyribonucleic acid homology, and proposal of seven neotype strains. Int J Syst Bacteriol 29, 273-282.

Thompson, S. S., Miller, K. B. \& Lopez, A. S. (2001). Cocoa and coffee. In Food Microbiology: Fundamentals and Frontiers, 2nd edn, pp. 721-733. Edited by M. P. Doyle, L. R. Beuchat \& T. J. Montville. Washington, DC: American Society for Microbiology.

Zanoni, P., Farrow, J. A. E., Philips, B. A. \& Collins, M. D. (1987). Lactobacillus pentosus (Fred, Peterson, and Anderson) sp. nov., nom. rev. Int J Syst Bacteriol 37, 339-341. 